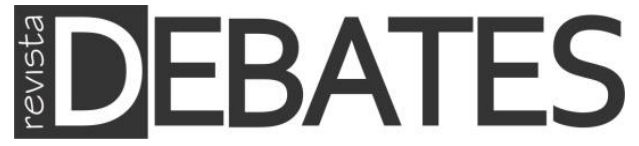

\title{
Temporality, causality and trajectories: comparative historical analysis in social and political sciences
}

\author{
Tempo, causalidade e trajetórias: análise comparativa histórica nas \\ ciências politicas e sociais
}

\section{Hélder Ferreira do Vale}

\begin{abstract}
The article closely examines the comparative methodology proposed under the "Comparative Historical Analysis" (CHA) approach. The purpose of the article is to highlight the advantages gained with the application of this comparative methodological approach in the interpretation of current complex events. In doing so, the article provides concrete guidelines on how to apply this approach to enhance historical comparisons. In attempting to accomplish these goals, the article pursues three tasks. First, it shows how historical comparisons are useful for the identification of the patterns, mechanisms and dynamics behind complex process in social and political sciences. Second, the article explains the methodological advantages of using CHA in complex historical processes and exploring some methodological innovations. And lastly, the article applies the CHA approach to two current events: the emergence of the armed group "Islamic State" and the Ukrainian-Russian territorial dispute. The article concludes that CHA provides an innovative comparative framework to understand complex historical process across countries.
\end{abstract}

\section{Keywords}

Qualitative Research; Historical Analysis; Comparative Methodology; Case Study; Causal Inference; Path Analysis.

\section{Resumo}

O artigo examina a metodologia comparativa proposta no âmbito da abordagem "Análise Comparativa Histórica” (CHA). O proposito do artigo é destacar as vantagens adquiridas com a aplicação desta metodologia comparativa na interpretação de eventos complexos da atualidade. Ao fazê-lo, o artigo propóe orientaçóes concretas sobre como aplicar esta metodologia para reforçar comparaçóes históricas. Na tentativa de alcançar esses fins, o artigo visa três objetivos. Primeiro, mostrar como as comparaçôes históricas são úteis para a identificação de padróes, mecanismos e dinâmicas por trás de processos complexos nas ciências sociais e políticas. Segundo, explicar as vantagens metodológicas da utilização da CHA em processos históricos complexos e explora algumas inovaçóes metodológicas. E, por último, aplicar as proposiçóes feitas pela CHA em dois eventos atuais: o surgimento do grupo armado "Estado Islâmico" e a disputa territorial russo-ucraniana. $\mathrm{O}$ artigo conclui que a CHA oferece um esquema comparativo inovador para compreender processos históricos complexo entre vários países.

\section{Palavras-chave}

Pesquisa Qualitativa; Metodologia Comparativa; Análise Histórica; Estudo de Caso; Inferência Causal; Análise de Trajetória. 


\section{Introduction 1}

This article ${ }^{2}$ highlights the important role that temporality and history play in influencing political and social outcomes through the lens of "Comparative Historical Analysis" (CHA). CHA is an approach that is used in the social and political sciences to explain complex historical processes through the comparison of cases.

Complex historical processes such as democratizations (HANSON, 2006; SLATER, 2010), formation and collapse of nation-states (LIPSET, 1990; MARX, 1996), the shaping of social movements and revolutions (SKOCPOL, 1979; SLATER, 2009) and the territorial organization of the state (RODDEN, 2005; ZYBLATT, 2006; FALLETI, 2010) have been systematically interpreted utilizing $\mathrm{CHA}$. These processes are complex as there is no single factor that causes them; that complexity can be attributed to the instability of social and political behavior as well as the changing nature of social and political institutions.

One of the critical issues that social and political sciences face is to develop theories to explain behavior and, therefore, social and political outcomes. However, thus far, these sciences have failed to propose lasting theories to explain and predict behavior. A possible problem with the lack of durable theories in social and political sciences is that these theories have tried to be predictive, resting on the assumption that we live in a stable world of institutions and behavior. As Blyth (2005: 497) rightly said "theories we develop about our world tend to assume much more stability, and thus predictability, than is warranted". In many ways, $\mathrm{CHA}$ tries to avoid these mistakes by assuming that the world is unstable, i.e., there is nothing static in a world heavily influenced by contextual conditions.

By looking at these complex social and political processes from both comparative and historic perspectives, it is possible to dissect their prevailing causes. Comparison between cases allows us to identify mechanisms behind complex historical processes such as revolutions, formation and collapse of new states, change in political regimes, and reforms of welfare systems. However, a careful and systematic comparison in the CHA tradition requires a specific understanding of temporality (e.g., sequence and duration of processes) and history. With this purpose in mind, this article presents a framework with which to study the role of history in political and social comparisons through the methodological lens of CHA.

Temporality plays a role in shaping developments in modern polities and societies. The passage of time in the form of a sequence of events can reveal

\footnotetext{
${ }^{1}$ This work was supported by Hankuk University of Foreign Studies Research Fund of 2015.

${ }^{2}$ The author would like to thank Ji-Hyun Lee and Min-A Kim for their research assistance.
} 
important patterns behind complex social and political processes. Yet our understanding of time is confined to a limited notion of history that interprets historical time as a natural passage from one period to the next that is punctuated by different events. The problem with this definition of historical time is that often historic narratives fail to build a coherent causal relationship between critical events and outcomes. Furthermore, analyses of processes with a long duration assume that history moves in one direction and that the outcome being analyzed is inevitable.

In order to make it relevant for social and political sciences, scholars should try to "model history", but that is not an easy task. It requires a careful conceptualization of time, the establishment of criteria for the identification of critical events and of the actors participating in these events, as well as the discovery of coherent mechanisms that link political and social contexts with the behavior of those actors. Following the tradition of historical comparativism, this article focuses on historical comparative inquiries that place higher importance on "how" rather than "why" questions. By putting special emphasis on how complex processes lead to a specific outcome, these processes can be compared across countries and time while making it possible to identify regularities.

The objective of this article is to deepen our knowledge of institutional developments through the lens of comparative history ${ }^{3}$. In this article, history and comparison have specific meanings. As far as history is concerned in CHA, differently from other approaches, historical processes are the result of an interrelated chain of events which create paths largely determined by the relationship among social and political actors, as well as by the interaction between these actors within the institutional context. The comparative feature of CHA is rather innovative as the contrast or similarity between cases is used to develop new theories, uncover conditions in the occurrence of an outcome, and to identify an underlining mechanism behind a process.

Under this specific conceptualization of history and comparison, at least three assumptions can be made about the application of CHA to the political and social sciences. First, CHA is rigorous about the selection of each event and, as such, is able to identify different periods in the unfolding of a process. Second, this approach interprets historical events as the result of rational actors who attempt to strategically influence the paths of a process and yet are able to adapt to contextual constraints.

\footnotetext{
${ }^{3}$ The notion of institutional development comes from the interpretation that historical events are the result of the influence of institutions on social and political agents. From this vantage, institutions are interpreted in this article as norms and rules that are products of historical processes, and that, once created, these institutions dictate behavior.
} 
The final outcome of a process being studied is a consequence of the type of interplay between the preference of actors and the institutional constraints. And lastly, the construction of a historical path is determined by a persistent mechanism that reveals a constant pattern over time.

The comparative element of CHA allows the analysis to be applied to different cases across time; essentially, this means that any analytical framework built using this approach can be applied to an historical process in different countries. Used for this purpose, the comparative framework must either systematically compare different processes across countries to explain how these paths led to similar outcomes, or contrast similar processes that have been changed in their unfolding, thus leading to different outcomes ${ }^{4}$. As this article aims to acquaint readers with the main tools to study the influence of history in cross-country comparisons, I will center the analysis on the critical elements of CHA, namely, critical junctures, modes of interaction between actors and institutions, and causal mechanisms. Through these elements, which are the backbone of the CHA's general framework, it will be possible to model history in order to understand complex processes.

Conducting proper $\mathrm{CHA}$ in the political and social sciences requires the analysis to be systematic, empirical, falsifiable and replicable. By being systematic, research can identify patterns behind the behavior of actors and illuminate how the final observed outcome came into being. The empirical facet of the analysis suggests that it must be based on historical evidence. The falsifiability indicates that, in any historical narrative, an alternative explanation to the outcome should be provided. Finally, the analytical framework should be replicable by providing a clear methodological framework. The analytical framework that this article attempts to propose includes all of these features. By highlighting these features in the CHA framework, the article attempts to enhance understanding and applicability of basic comparative methods to historical processes.

The article is divided in five parts, including this introduction. In the next section, I discuss the role of history in political and social sciences and then explain the main methodological contributions of CHA to comparative studies and the methods to be employed in order to analyze historical processes. In the following section, I will apply the building blocks of CHA to analyze state formation in the Middle East through a brief comparison between the so-called Islamic State and Hezbollah, and territorial conflict in East Europe through an overview of Ukraine's

\footnotetext{
${ }^{4}$ The comparative logic used is either that of "most-similar" or "most-different" methods.
} 
and Georgia's territorial conflict with Russia. The conclusion briefly discusses the implications of CHA in the field of social and political sciences.

\section{The Role of History in Political and Social Sciences}

This section discusses the various uses of history in social and political sciences, outlining the different models of institutional development currently in use by contrasting CHA with so-called "Historical Institutionalism" (HI). Different approaches and models will also be discussed. This section will conclude with an explanation as to the ways in which history can aid us in understanding institutional changes in modern states and societies.

Methodologically, over the past years, history has been approached in the social and political sciences under HI. The main presumption of $\mathrm{HI}$ is that history is constructed under the influence of institutional structures on individual or collective behavior. However, this relationship between institutions and behavior is complex as actors attempt to influence institutions (STEINMO, 2008). This approach represented a methodological shift in how the political and social sciences had been studied and applied, as it established a new form of inquiring about how political and social processes develop over time 5 . As opposed to other approaches (e.g., rational choice), HI sees institutions as the result of historical processes and not necessarily as the outcome of efficient equilibrium as other approaches postulate ${ }^{6}$.

Despite the contributions of $\mathrm{HI}$ to our understanding about the dynamics behind the complex relationship between institutional rules, context and actors' behavior, it failed to provide answers to questions about how institutional change and maintenance take place. By being unable to establish parameters on the patterns of institutional transformations, this approach only provides general guidelines to interpreting the following triad: rules, behavior and context. In effect, HI has been criticized by being too general to be applied to any complex historical process (LEVI, 2002).

Due to the inability of $\mathrm{HI}$ to sketch a clear framework with which to study complex historical processes, CHA, being more fine-grained, is intended to address

\footnotetext{
${ }^{5}$ It is important to mention that HI has drawn several of its building blocks from rational choice and the commonalities between both approaches are larger than the literature recognizes (THELEN, 1999, p. 371).

${ }^{6}$ Under the rational choice approach, institutional equilibrium is maintained if institutions are selfenforcing and provide incentives for cooperation. These conditions are met as long as institutions coordinate actions of individuals by imposing constraints on them (CALVERT, 1995).
} 
the main criticisms made against $\mathrm{HI}^{7}$. As a comparative approach, $\mathrm{CHA}$ provides us with methodological tools to assess political and social process across countries and time, which is precisely what sets CHA apart from $\mathrm{HI}$ in terms of methodology. The main methodological proposition of CHA is that outcomes in social and political sciences are not the result of a single event, but instead of several interrelated events. The context in which these events take place is the main shaper of collective and individual decisions and actions. CHA sees these events as the result of interactions (e.g., conflict, coordination, bargaining) between actors. As a consequence, any observed outcome can be traced to a sequence of events that often, due to contextual changes, have transformed institutions.

One of the critical questions that CHA attempts to address is how to build a causal argument that connects the observed outcome with the several events that make up a process. In historical narrative, causation is built differently from other forms of causation (MAHONEY, 1999) ${ }^{8}$. The key difference is that in historical analysis, events are interrelated by a mechanism that leads to an outcome. This mechanism in historical narratives has different conceptualizations. Mahoney (2012) simply defines it as an intervening variable; Stinchcombe (1991) interprets this mechanism as a permanent social instrument that leads to an outcome; and Falleti and Lynch (2009) propose a more specific definition since they understand causal mechanism as providing the linkage between actions and events by connecting the micro dynamics and macro events.

The difficulty in identifying causal mechanisms in social sciences lies in the problem of isolating social dynamics to observe social outcomes; this, in turn, stems from the inability of researchers to control the process in question (PRZEWORSKI, 2009). It is mainly for this reason that there are few identified mechanisms in social and political sciences, as opposed to the natural sciences. Due to the difficulty of identifying causal mechanisms, social and political sciences have avoided the construction of grand theories and have become more focused on producing middlerange theories. In contrast to grand theorization, when theorizing under a middlerange approach, scientific knowledge is employed to explain a phenomenon that is based on certain conditions'. Furthermore, in order to determine these conditions,

\footnotetext{
${ }^{7}$ Despite the disagreements, CHA has largely drawn on HI, as Mahoney and Rueschemeyer (2003, p. 15) claim.

${ }^{8}$ Mahoney (1999) identifies three types of causation: nominal, ordinal and narrative.

${ }^{9}$ Merton (1968) was one of the first scholars to propose the abandonment of grand theories in order to produce middle-range theories, which, according to him, would be based on minor hypotheses that, once systematically assessed, could build cumulative knowledge.
} 
researchers will make use of several interrelated theoretical propositions that incorporate a comprehensive number of explanatory factors (MUNCK, 2010).

In causal narratives, which attempt to dissect and explain complex problems, the several events that lead to an outcome can rarely be explained under a single theory. Indeed, causal narratives are conducted via a symbiosis of interrelated propositions that must be empirically tested, which is often done through the observation of explanatory factors that lead to a causal outcome. In terms of theorizing the outcome of the causal analysis, CHA attempts to generate conditions under which this outcome can occur elsewhere. Also, these conditions are essential to determining why this outcome might in fact not be observed elsewhere.

As already mentioned, in causal narratives, there are multiple factors influencing an outcome in different cases. The conditions of necessity and sufficiency assist us in determining the relevance of the effect of the different causal factors behind an outcome. In causal narrative, the condition of necessity is very important because it allows a researcher to assess a counterfactual situation, which basically means that the absence of a condition would prevent an outcome from happening. The search for a necessary condition based on a counterfactual explanation points to a single cause. However, the search for a single cause in complex process is hardly possible. Necessity is particularly difficult to identify in causal processes as single case causal processes are often very deterministic. For example, the absence of one event based on the evidence of a single case process can mislead us into concluding that it is a necessary condition (GOERTZ and LEVY, 2007) ${ }^{10}$. That said, CHA researchers have difficulty finding necessity conditions.

As to sufficient condition, this condition is useful for us when assessing the different paths to an outcome (MAHONEY and GOERTZ, 2006, p. 232) as, essentially, this condition assists in determining different factors in a process that contribute to an outcome. Even if a condition is insufficient, it can be an important part of the explanation because it might have a joint effect once it is associated with other conditions (HAWKINS, 2009) ${ }^{11}$. This means that the condition of sufficiency is met by joint factors instead by a single factor. Since there are multiple factors, it is important to link them to a specific context in order to elaborate on the sufficient conditions.

\footnotetext{
${ }^{10}$ Goertz and Levy (2007, p. 13) call this "necessity condition counterfactual".

${ }^{11}$ In causal narratives, sufficient conditions are difficult to find provided that are several sufficient conditions that lead to the same outcome although through different paths.
} 
In qualitative analyses comprising several factors that influence an outcome, the necessary and sufficient conditions are not easy to identify, and as such, it is important to elaborate mid-range theories. There are three central reasons that attempting to produce mid-range theories is consistent with CHA. First, CHA has a strong experimental orientation that attempts to reveal the effects of the cause, which differs from the cause of effects. Second, CHA borrows from different theoretical frameworks to explain an outcome, and thus puts special weight on the context in which a phenomenon occurs. And, third, CHA is concerned with "real world issues" that are addressed in comparative terms.

Utilizing the CHA approach, history is written under a causal logic. However, this logic is not easily uncovered, and, as such, the purpose of researchers using the CHA approach is to unveil this logic. In order to do so, historical events are carefully studied as the result of a strategic interaction between actors and the institutional setting. Depending on the country-case, the sequence of events presents different trajectories that can lead to a similar outcome, or similar trajectories might result in different outcomes. This puzzle can only be resolved through contextualization of the process being analyzed. By contextualizing historical processes, CHA is able to produce mid-range theories instead of grand theories.

\section{Comparative Historical Methods and Methodology}

This section outlines the main building blocks underlying the framework necessary to conduct comparative historical research, meaning that the article turns to the question of how to structure history around different periods divided by critical junctures and turning points. I will then explain how to assess causality in historical episodes. Finally the article addresses the question of how to make use of historical evidence by tracing processes ${ }^{12}$.

CHA is founded on strong empirical grounds. In contrast to other traditions that follow a deductive logic (e.g., rational choice theories), CHA is grounded on empirical observations that are used to formulate new theories ${ }^{13}$. Concretely, this means that in attempting to understand the interaction among actors and institutions

\footnotetext{
${ }^{12}$ The notion of tracing a process differs in this article from the notion of "process tracing", which can be defined as a method of discovering causal mechanisms under specific guidelines. Most accounts of process tracing a single method perceive it as a deductive process in which "the researcher looks for a series of theoretically predicted intermediate steps" (CHECKEL, 2008, p. 363).

${ }^{13}$ Rational choice, for example, focuses on the imputation of preferences of actors, which is based on a deductive rational. The purpose of this theoretical imputation of preferences is to predict patterns of behavior. As such, unlike CHA, the rational choice has a tendency to focus on theoretical prediction.
} 
in a given process, analysts who apply the CHA approach try to observe patterns of interaction between actors, which in turn are based on the strategies of actors.

The concern that CHA has for empirical analysis places particular emphasis on the case studies. It is through a small number of cases that research based on CHA will make normative contributions. This also means that the comparative feature of CHA allows one to create a framework of analysis to arrive at sound explanations on the main causes of an outcome. However, the comparative analysis used under the CHA tradition is different from other small-N comparisons in social and political sciences. While comparisons under CHA follow the same comparative methods as other traditions (most different and most similar research designs), several other aspects of CHA differ: it places greater weight on the context; both dependent and independent variables vary over time, meaning that a dependent variable can become an independent variable in a different period of analysis; and the purpose of the comparison is to find conditions behind an outcome. The best way to understand the particularities of CHA is to contrast it with the widespread method of comparative statics $^{14}$.

CHA is different from the comparative statics. Essentially, the focus of comparative statics is mainly on why change occurs, instead of how change takes place. Comparative statics examine one variable while holding constant all other variables of the selected cases, and assessing how this variation impacts on the outcome (DELLA PORTA and KEATING, 2008, p. 349). This type of logic requires a framework of analysis in which the variables are identified a priori and the cases are strictly guided by these variables.

Differently from comparative statics, CHA focuses on change through the lens of temporality. Under this lens, there is an attempt to dissect how the different elements involving the interaction between actors lead to change ${ }^{15}$. It is important to keep in mind that institutional change is often incremental and seemingly small adjustments can culminate into significant institutional transformation (MAHONEY and THELEN, 2010, p. 16). It is possible to suggest that under the CHA tradition, the role of institutions is to mediate interaction among actors. As such, institutions

\footnotetext{
14 Adrienne Héritier (2008) identifies two comparative traditions to explain complex historical political phenomenon. One of these traditions is "comparative statics" and the other is CHA.

${ }^{15}$ Mahoney and Thelen (2010) emphasize that change and stability are inextricably linked and affirm the generally held assumption that institutions either break down or change over time. Following Streeck and Thelen (2005), they delineate four types of institutional change: displacement, layering, drift, and conversion.
} 
are instruments that shape ongoing struggles that occur within and over prevailing institutional arrangements.

For heuristic purposes, case studies under CHA are often aimed at discovering new variables, hypotheses, and causal paths and mechanisms ${ }^{16}$. This is largely an inductive process in which the researcher utilizes the cases to build a coherent argument that is consistent across those cases ${ }^{17}$. Following a heuristic strategy, one has to consider objectives that may not be optimal, but that allow the researcher to analyze the cases within a socio-historic context. Unlike in comparative statics, deviant cases may be particularly useful for heuristic purposes, as these cases present outcomes that are explained by most theories.

The particular concern of explaining change or the lack of stability under CHA is to build a causal chain of events leading to the outcome. In building this causal chain, CHA research should focus on decision formation. In explaining how decisions came into being, it is impossible to isolate the factors that contributed to the causal process being studied.

\section{Causal Process under CHA}

Starting from the premise that complex political and social outcomes can be explained through the preferences and strategies of political and social actors, CHA may employ the so-called "soft rational choice" to understand changes and continuities in formal institutions. The emphasis on formal institutions does not mean that political and social actors are not engaged in extra official interactions. However, we are only able to consistently observe formal processes, through which the motivations and preferences of collective actors will be used to explain their interaction with the institutional setting.

\section{Actors and Preference Formation}

Any systematic cross-country analysis is based on certain building blocks; therefore, this article will proceed to discuss historical processes by exploring the

\footnotetext{
${ }^{16}$ George and Bennett (2005, p. 20) point out that, in the social sciences, researchers are not typically looking for a causal explanation, so case selection is an opportunistic as well as a structured process. Therefore, various heuristic devices, such as process tracing, are deployed to work toward the research objective.

${ }^{17}$ The objective of the research largely determines the cases being studied. George and Bennett (2005) identify several types of research objectives that will determine the case studies. For the most part, the research can be of three types: theory development, theory testing or heuristic purposes.
} 
following questions: who are the main political actors involved in the process; what are the actors' preferences and strategies; and how does the interaction between actors and formal institutions lead to a specific outcome? Any research inquiry under CHA that seriously intends to answer these questions will recognize the main decision makers in a process, identify their preferences over time, divide the process in different periods, and trace distinct trajectories of the process to a given outcome.

The identification of relevant players in a process is not always an easy task. In a complex process, it is very rare for a single actor to make decisions in isolation from the context and preferences from other actors. Instead, decisions are the result of an adaptation of an actor's preferences to those of others and to the specific context.

CHA usually works within the premise that complex political and social outcomes can be explained through the preferences and strategies of political and social actors. Preferences lie at the heart of political and social decisions and actions; by using them as the focus of analysis, any $\mathrm{CHA}$ research attempts to explain individual or collective optimal choices.

The first task in the analysis of preference consists of enumerating feasible choices of actors and the order of importance given by individual or collective actors to each of these choices. The enumeration in order of preference forms a system of preferences for each actor. Under this system, actors attempt to maximize their expected payoffs by pursuing a strategy, which may be that of cooperation or conflict with other actors. For this reason, in any given process, preferences reveal the type of relationships actors have among themselves and with institutions. Preferences after all are formed in an institutional setting in which relationships and interactions are established, thus becoming "situationally induced preferences" (KATZNELSON and WEINGAST, 2005, p. 4).

The above interpretation of preferences suggests that they are not rigid, but instead are malleable to an institutional context that sets different incentives for interaction. This rationale also suggests that actors participating in the interaction game can strategically adapt their preferences; therefore, in any process, the preferences of actors change over time.

This adaptation of one's preference can often lead to institutional changes. However, changes often involve conflict as the introduction of new institutions and some actors try to block any change. These actors are known as veto players, who use their institutional power to block any action that attempts to change the status quo. 


\section{Periodization of Processes}

Any systematic comparative analysis focusing on a historical process needs to break down these processes into different periods. This division of processes into periods is called periodization. The purpose of periodization under CHA is threefold. First, it allows for the identification of changes in preferences and strategies of actors. Second, periodization allows researchers to recognize how different factors are influencing the process. And, third, periodization increases analytical precision as it is possible to observe how a potential causal mechanism is operating.

Periodization is intrinsically related to preference formation as structurally different periods in a process delimit the scope of actions of actors and might present them with new opportunities for action. As Katznelson (2003, p. 280) explains, "Usually large moments of decisive change [...] are products of the configuration of big processes that constrain individuals by placing them in situations where their identities, values, beliefs, intentions and strategies are compressed into a gelatinous sets of preferences". Put differently, the periodization of a process allows one to understand how temporality molds an actor's behavior.

One of the critical problems in applying periodization is identifying when a period ends and a new period starts. This is a problem related to the hierarchy of events, which indicates that some events and moments are more relevant than others. For instance, critical junctures, which are rare moments in the history of a country when institutions cease to exercise constraints on the actions of actors (CAPOCCIA and KELEMEN, 2007), are extremely relevant to the understanding of any process.

These critical junctures are moments in which new actors are created, actors attempt to gain influence, and new modes of interactions are produced. As such, any historical analysis of a process must have a detailed analysis of critical junctures. Given the relevance of critical junctures, a comparison of processes across countries starts at this point. The identification of other events that are not necessarily critical are also important for the periodization. Non-critical junctures are events that mark a shift in the interaction among actors and institutions. These moments indicate that a path to the outcome can either be reinforced or overturned.

Once a critical juncture and other important events are identified, the periods into which a process is divided allow researchers to operationalize the different modes of temporality. For example, there is the possibility of observing a sequential pattern of events. Moreover, it is feasible to analyze the duration of the events and the consequence to the interaction between actors. 


\section{Trajectories to Outcome(s)}

$\mathrm{CHA}$ identifies trajectories towards an observed outcome that can be used as conceptual devices to build generalizations about causal influence. These events form paths towards an observed outcome. Equifinality and path dependence are two concepts used to interpret the different trajectories of processes.

Equifinality suggests that there can be various causal paths to an outcome. More specifically, it refers to circumstances wherein different historical causes or sets of causes may produce the same or similar outcome. Path dependency is the mode in which past decisions constrain the actions of actors, thus narrowing the possibility of changing paths. As the narrowing of the path occurs under specific conditions and incentives, it is possible to identify a necessary cause behind a path-dependent trajectory ${ }^{18}$.

These concepts are not mutually exclusive. However, the presence of equifinality makes it difficult to find a necessary condition of a causal relation when we try to identify a pathway in the historical context. Differently, for trajectories built under path dependency, the initial conditions of that path become necessary conditions. In other words, researchers explaining equifinality should look for a combination of facts or sufficient conditions for an outcome while those researching path-dependent outcomes should look for necessary conditions.

Both devices are well-established conceptual tools under the CHA approach, although the path dependence has gained greater attention over the past years. However, the problem with path dependence is that of finding a necessary cause that creates a common path dependent trajectory across cases. As causal homogeneity cannot be sacrificed in comparative analysis, a path-dependent trajectory across countries can be elusive.

\section{Comparative Historical Analysis and Current Themes}

In order to understand the usefulness of CHA in interpreting current events that have been gaining international attention, the article will briefly analyze the emergence of the so-called Islamic State (IS) and the territorial conflict between Ukraine and Russia in light of the annexation of Crimea in 2014. These issues fall under classic themes studied in comparative politics. The case of the emergence of IS is related to the failure and creation of states. The case of the international territorial

\footnotetext{
18 There are several other elements that indicate the presence of path dependence such as increasing returns gained from making some decisions, and the self-enforcing mechanism that these decisions possess (PIERSON, 2000).
} 
conflict in Ukraine is more directly related to the ethnic territorial conflict in the process of state formation.

The purpose of approaching current topics from a comparative perspective is to show how to apply the general guidelines under CHA. Researchers who use CHA should follow these steps in producing a causal narrative: structure the research around a problem or a puzzle; elaborate on a set of interrelated propositions around variables; identify critical events and the main actors involved; and detect the similarities and differences to trace the trajectories of processes across cases.

One of the main problems in assessing these events is their relative newness. However, if we look at these events more closely, it is possible to find some historical parallels. For example, the emergence of IS in Iraq can be compared to the emergence of Hezbollah in Lebanon in the early 1980s. The international territorial dispute between Ukraine and Russia finds some parallel in the territorial crisis between Georgia and Russia in 2008.

Following some of the general guidelines offered by CHA, it is possible to create a coherent analytical framework to interpret "real world problems". The purpose of this exercise is to give a broad overview of these issues and, under CHA, provide a basic framework of how to approach them. This means that at least two important features of historic narratives conducted under CHA - the use of thick description and the attempt to uncover causal mechanisms - will be missing from the analysis. Given the space and the nature of the CHA research, it is only possible to provide a sketch of the initial steps necessary to conduct research under $\mathrm{CHA}$.

\section{IS and Hezbollah}

The influence that both IS and Hezbollah exercise in the regional politics of the Middle East is an issue that has sparked a great deal of interest in both the academic and political worlds. The stories of these groups, from their emergence to their consolidation as influential non-state actors operating under religious grounds, can teach us about the conditions under which these actors became relevant regional players, conceptualized here as actors with the capacity to influence decision making across several countries in a geographic location.

IS became a well-known international armed group as its members came close to overthrowing the Iraq government by being able to march over Baghdad in early 2014. By then, IS had already gained military control of a vast territory in Syria and Iraq. In many ways, this was unprecedented in the recent history of the Levant, a Middle Eastern area often controlled by strongmen, i.e., that an armed group in a 
short span of time maintained the deployment of violent tactics in such a large territory.

In order to explain how IS and Hezbollah became influential regional actors, which is a common outcome, the research has to show that despite several differences, the paths of these groups converged. A systematic application of CHA elements can help us to solve this puzzle. The research puzzle presented here is a case of equifinality as different paths can lead to a similar outcome. In this case, there is no necessary condition that justifies the outcome provided that different factors produced the same end result. As such, the research should focus on the sufficient conditions. In order to determine these conditions, inevitably, one must engage in a historical analysis.

The initial step in designing a CHA research of this topic is to identify the similarities and differences between IS and Hezbollah (see Table 1). There are several similarities between both groups. First, both groups had been originally formed around warfare. Second, these groups became independent from a mother organization (Amal in the case of Hezbollah and Al Qaida in the case of IS). Third, the regions where these groups thrived have been dominated by colonial powers, namely Britain and France, that favored one local group over the other, thus leading to significant conflict in the foundation of countries in the region. And, fourth, these groups gained strength due to conflict in neighboring countries (e.g., the Syrian civil war).

There are also some important differences between IS and Hezbollah (see Table 1). Although both groups attempted to provide protection in a context of potential violence, Hezbollah provided local security mainly due to a troubled context of violence in which the Shia's were notoriously targeted ${ }^{19}$. In a different institutional setting, the mother organization of IS, Al Qaida, was engaged in an international jihadist mission. Another well-known difference has to do with the number of groups against which the original founders of IS and Hezbollah were fighting. While the mother organization from which IS sprang was fighting a foreign invader, initially, the Soviet Union in Afghanistan and currently, effectively fighting the governments of Syria and Iraq, Hezbollah was engaged with foreign (e.g., the Palestine Liberation Organization - PLO, and the Israeli army) and domestic enemies (e.g., the Maronite majority and the Arab Sunnis).

\footnotetext{
19 This interpretation of the role of Hezbollah comes from the recognition that it played a legitimate social agent role in a context of poverty and violence (KNIO, 2013).
} 
Another important difference is the financial support of both groups. Hezbollah has enjoyed stable support from the Iranian government. In contrast, IS initially drew support from various international private and public donors, and financed its actions through rent from oil exploration in its conquered territories. The tactics of survival have been different in the two cases. Whereas Hezbollah has formally participated in the political arena in Lebanon as a formal political party, IS has not used this method in Iraq, preferring to pursue warfare tactics. Indeed, unlike IS, Hezbollah is not a monolithic movement; it has different identities (ALAGHA, 2006). Furthermore, Hezbollah has not only used military tactics; it has used poverty to promote what some have called "Islamic populism" (SALMEY and PEARSON, 2007). Finally, a major difference is that within Islam, these groups have different religious orientations as IS is Sunni and Hezbollah is Shiite. Due to their religious orientation, each group has a different social and political status in their respective countries. Historically, Shiites were marginalized in Lebanon, while Sunnis in Iraq have enjoyed a privileged position vis-à-vis Shiites.

Table 1 - Similarities and Differences between IS and Hezbollah

\begin{tabular}{l|l}
\hline \multicolumn{1}{c|}{ Similarities } & \multicolumn{1}{c}{ Differences } \\
\hline Warfare as original purpose & $\begin{array}{l}\text { The focus of warfare varied: one was domestic and } \\
\text { the other was international. }\end{array}$ \\
\hline Split from a mother organization & Number of domestic enemies differed \\
\hline $\begin{array}{l}\text { Countries of origin were socially and politically } \\
\text { divided by colonial powers. }\end{array}$ & Source of financial support varied \\
\hline $\begin{array}{l}\text { Conflict in neighboring countries strengthened } \\
\text { the domestic and international influence of } \\
\text { these groups. }\end{array}$ & Distinct religious groups (e.g., Sunni and Shia) \\
\hline
\end{tabular}

Source: Own elaboration.

All of the above factors have led to the transformation of both IS and Hezbollah. The several modifications that IS underwent in a rather short time span to arrive at its current configuration is telling of the multiplicity of factors that have shaped the formation of this group. Most of these factors are structural and made Iraq a perfect setting for the creation and consolidation of IS (NUNEZ 
VILLAVERDE, 2014). The origin of IS can be traced back to Al-Qaeda, founded in 1988 to fight against the former Soviet Union in its invasion of Afghanistan.

As a religion organization, Al-Qaeda was motivated to protect the local Muslim religious values from the invaders in a context of war. However, over time, with the change in the international political order and with the growing radicalization of Al-Qaeda, which started to dominate the socio-political dynamics in Afghanistan, there was a growth of anti-American sentiment. Utilising this sentiment, Al-Qaeda expanded its influence throughout the Middle East, recruiting local representatives in several countries.

Al-Qaeda in Iraq (AQI) was created by Abu Musab al-Zarqawi, a Jordanian national who went to Iraq in 2001 and who formed his own terrorist group that mainly targeted foreigners and Shiite Muslims in that country. In 2004, Zarqawi changed his group's name to Al-Qaeda. With the death of Zarqawi in 2006 under attacks by the USA and Iraq intelligence agencies, Abu Ayyoub al-Masri became the new leader of the group and amalgamated AQI into the so-called Islamic State of Iraq (ISI). A few years later, international military forces killed Masri, and Abu-Bakr alBaghdadi became the new leader of the group, changing its name to the Islamic State of Iraq and Levant (ISIS) in $2013^{20}$. At this point ISI had already a very different goal from Al-Qaeda. While the latter was mobilizing Muslims against secular states in the West, the former intended to conquer territory to form a Sunni state (CRONIN, 2015).

As for Hezbollah, its transformation was marked by a survival tactic that allowed a social movement to eventually become a political party (CHILDS, 2011). Hezbollah's original organization, Amal, was founded in southern Lebanon during the fight against the Palestine Liberation Organization (PLO). Though the history of Hezbollah is not as complex as that of IS, Hezbollah also started with an organization named Amal. Established in 1975 under the leadership of a Shiite Imam, Musa alSadr, the movement attempted to provide local security. Later, it developed into a Shiite political party in Lebanon. However, Amal's inclination towards downplaying religion to a minor role in political issues created some division and a new organization, Islamic Amal, was established in 1982, with Ayatollah Ruhollah Khomeini as the head of the group. Under the direction of Khomeini, the group's name was revised to Hezbollah, the Party of God.

\footnotetext{
${ }^{20}$ Abu-Bakr Al-Baghdadi, the chief commander of IS, founded the rebel group Al-Nusra Front (JN) in Syria amidst the chaos created in the Syrian civil war. However, JN remained affiliated with Al-Qaeda while Al-Baghdadi decided to split from Al-Qaeda, giving birth to IS.
} 
It is important to observe a critical juncture in the process that these groups underwent before becoming influential regional players. A turning point seems to have been the wars in which these groups gained important leverage. In the case of Hezbollah, this critical juncture was the Lebanese Civil War (1975-1990) and, in the case of IS, was the Syrian Civil War. Following these critical junctures, the role of these groups was augmented, with the civil war in Lebanon providing more power to Hazbollah (NORTON, 1987).

The initial step in conducting a CHA inquiry was to pinpoint the similarities and differences between the cases. In this task, given that the observed outcome is similar between the cases - the consolidation of the non-state actors as regional players through the use of violent practices - this brief analysis focused on factors that, in both cases, led to the convergence of outcomes. After describing the critical junctures in the two cases, i.e., the civil wars in Syria and Lebanon, it is possible to see that these events allowed Hezbollah and IS to consolidate their warfare power. However, for a more fine-grained assessment under a CHA framework, the analysis should take additional steps such as dividing the evolution of IS and Hezbollah into different periods (periodization) and identifying the evolution of dynamics among actors in each period.

\section{Regional Territorial Conflict in Ukraine and Georgia}

Since the disintegration of the Soviet Union, Ukraine and Georgia have had a contentious relationship with Russia over territorial issues. Until the occupation of Ukraine, Russia created four "breakaway ethnic regions": Transnistria in Moldova, Abkhazia and South Ossetia in Georgia, and Nagorno-Karabakh in Azerbaijan (MANKOFF, 2014). These are auto-proclaimed independent states that have the political and military backing of Russia but are considered to be integral parts of the territory of Georgia, Moldova and Azerbaijan by the central governments of these countries. However, the conflicts in these regions have not turned into a full-blown war.

The question that raises research interest regarding these conflicts is: why has Russia turned the territorial conflict in Ukraine into a war, while the other territorial conflicts in Eurasian countries have become frozen conflicts? The Ukrainian-Russian conflict, which culminated in the annexation of Crimea in 2014, has raised concern that the international community could be polarized in a conflict between Russia and the USA (and its allies), resembling the Cold War dynamics. This conflict has been considered the gravest crisis in Europe since the end of the Cold War. Similarly, in 2008, Georgia's territorial dispute with Russia was considered to one of the most 
serious international conflicts. At the time, both countries exercised some restraint due to fears of an escalation of tensions that could lead to war. It is important to note that the Ukraine crisis is still unfolding, while the conflict between Georgia and Russia came into a standstill.

The territorial conflict involving multiple domestic and international actors in the Ukraine and Georgia invites us to think about the changing international world order. Through the conflict in these countries, it is possible to understand the tactics of global and regional powers in attempting to cooperate and/or deploy military power in order to accomplish their international policy goals. Moreover, the military dispute involving Russia in Ukraine and Georgia provides hints about how military conflict emerges among neighboring countries and the implication of Russian and EU foreign policy in the prospects of democratization in Eastern Europe and Eurasia (TOLSTRUP, 2009).

This issue is appropriate to be analyzed under the CHA framework mainly because it involves large numbers of decision makers in a multi-level policy context, meaning that there are overlapping institutional constraints (e.g., the European Union, the international community, and the Russian "near abroad" policy) that actors involved in the conflict face. The recent territorial conflict cannot be fully understood without creating a chain of events involving the creation of new states in light of the disintegration of the Soviet Union, the enlargement of the European Union (EU), and the Russian desire to exert more influence in the regional and international arenas.

There are several similarities between Ukrainian and Georgian cases: the possibility of joining the EU and the North Atlantic Treaty Organization (NATO), two organizations that alienate Russia; strong economic ties with Russia; a domestic divide in terms of support for Russia and the EU, with the latter enjoying greater popular support than the former; and the official open negotiations with the EU for greater economic cooperation (see Table 2).

An important similarity between both countries, in addition to having been part of the former Soviet Union, is that both are attempting to become members of the EU. This is an essential part of the conflict with Russia, which is trying to maintain an influence in the countries of its "near abroad" 21 . Russia's "near abroad" policy, generally speaking, consists of maintaining a hegemonic political and

\footnotetext{
${ }^{21}$ The "near abroad" is a concept used to refer to the territories that belonged to the Soviet Union and that have been continuously part of the Russian empire since the 17th century (PORTER and SAIVETZ, 1994).
} 
economic influence in the neighboring countries. Part of the objective of this policy is to create a strong pro-Russian sentiment that will culminate in support of these countries for any Russia policy initiative in the region and beyond. In order to legitimize this approach, Russia often claims that it has a natural stake in its neighbors' affairs as ethnic Russians represent an important percentage of the population of these neighboring countries.

Another relevant actor in Eastern Europe and in Eurasia is the EU, which opened the opportunity for several countries in this region to aspire to become EU member states. Ukraine and Georgia are part of the EU's Eastern Partnership (EaP) framework, which was launched in 2009 to enhance the bilateral relations between the enlarged EU with six of its Eastern European neighbors (i.e., Armenia, Azerbaijan, Belarus, Georgia, Moldova and Ukraine) ${ }^{22}$.

Largely under the influence of these two regional actors, domestic politics in Ukraine and Georgia have been dictated to a large extent by the chiasm between proRussian and pro-European supporters. Growing tensions between these two groups have led Russia to justify any territorial-military intervention in these countries. As a counter reaction, these countries have become more engaged in building closer economic and political ties with the EU. Yet, the EU engagement with Eastern European countries has been deemed erratic (LANGBEIN and WOLCZUK, 2012) and the EU promotion of democracy is more formal than substantive (CASIER, 2011). As a result, EU engagement and democratic promotion have had different effects (SASSEA, 2013).

\footnotetext{
${ }^{22}$ The EaP, which is part of a larger EU policy, the European Neighborhood Policy (ENP), provides an opportunity to enhance bilateral cooperation; however, there have been no formal negotiations for membership of these countries into the EU.
} 
Table 2 - Similarities between Georgia and Ukraine in the conflict with Russia

\begin{tabular}{l|l}
\hline \multicolumn{1}{c|}{ Similarities } & \multicolumn{1}{c}{ Differences } \\
\hline Possibility of joining the EU and NATO & Paths towards democratization \\
\hline High linkages with Russia & Paths to support EU integration \\
\hline $\begin{array}{l}\text { Domestic high anti-Russian sentiment and high } \\
\text { pro-EU sentiment }\end{array}$ & \\
\hline $\begin{array}{l}\text { Official willingness to be part of the EU } \\
\text { integration }\end{array}$ & \\
\hline
\end{tabular}

Source: Own elaboration.

In the case of Georgia, the hopes of democratization, which started with the Rose Revolution of 2003, were frustrated by a slow imposition of political limitations on the opposition, culminating in the mass protests in the autumn of 2007. Following the declaration of a state of emergency, presidential and parliamentary elections were held, leading to the further alienation of the opposition. With growing domestic instability, Georgian President Mikheil Saakashvili attempted to strengthen ties with the EU and NATO. Amidst growing accusations of President Saakashvili's authoritarianism and the weakness of state institutions, two regions populated by ethnic-Russians, Abkhazia and South Osseti, declared independence with the support of Russia. In the face of a possible escalation of the conflict, both sides exercised mutual restraint.

In the Ukranian case, the road to democratization depended on the type of president ruling the country. Ukraine's pro-West political elites tend to favor substantive democratization while pro-Russian political elites are inclined to support a limited democratization. In November 2013, after years of political fighting between these two groups, mass protests followed Ukrainian President Yanukovych's decision to abandon talks with the EU and to seek closer ties with Russia. The protests grew larger over time, and in January 2014, the police resorted to violence, killing several protestors. In a backlash, demonstrators occupied public buildings, demanding the release of jailed protestors, limitations on the power of the president and a continued dialogue with the EU. In February 2014, President Yanukovych sought refuge in Russia after the Ukrainian Parliament removed him from office. In Crimea, pro-Russian protestors took the streets and gunmen invaded the Crimean parliament and were immediately backed by Russia, who sent troops to Crimea. In March, with parliamentary approval, Russian President Vladimir Putin made the decision to annex Crimea. In the meanwhile, Russia opened a new battlefront in east Ukraine by providing military backing to an armed separatist movement. 
In order to analyze the different military outcomes faced by Ukraine and Georgia in relation to Russia, it is necessary to identify a common critical juncture. This critical juncture for Ukraine and Georgia was the collapse of the Soviet Union. The first period goes from this critical juncture to the independence movements that lasted until early 2000s. The second period refers to the attempts at democratization in these countries in 2003 and 2004. The main events in this period are referred as "revolutions", given the importance of mass protests pushing for democratizing reforms. After this period, a third phase emerged when Georgia and Ukraine attempted to accelerate negotiations for their accession to the EU.

The democratization process has proven to be a key element that led both countries to have different types of conflict with Russia. The periodization of the events demonstrates that until 2004, the national political elites in Ukraine and Georgia cooperated with the EU. The bifurcation between both countries only began after 2004, when each country took a different stance in relation to the democratization process (see Table 3). This process, in turn, conditions the type of relationship Ukraine and Georgia will have with the EU and other pro-Western allies: with higher engagement of pro-Western allies with democratizing Ukraine, Russia will be more willing to go to war. The opposite occurs with the increasingly authoritarian Georgia.

Table 3 - Periodization of the territorial conflict with Russia in Ukraine and Georgia

\begin{tabular}{l|l|l|l}
\hline & \multicolumn{1}{|c|}{$\begin{array}{c}\text { T1 } \\
\text { (1991- early 2000s) }\end{array}$} & \multicolumn{1}{c}{$\begin{array}{c}\text { T2 } \\
(2003-2004)\end{array}$} & \multicolumn{1}{c}{\begin{tabular}{c}
\multicolumn{1}{c}{ T3 } \\
(after 2004)
\end{tabular}} \\
$\begin{array}{l}\text { National } \\
\text { political } \\
\text { elites }\end{array}$ & $\begin{array}{l}\text { - Stable under the } \\
\text { hierarchical relations } \\
\text { with Russia } \\
\text { - Low inclination to } \\
\text { democratization }\end{array}$ & $\begin{array}{l}\text { - Unstable, with growing } \\
\text { mass demands for } \\
\text { democratization } \\
\text { - Higher inclination } \\
\text { towards democratization }\end{array}$ & $\begin{array}{l}\text { - Persistent instability with } \\
\text { challenges of democratization }\end{array}$ \\
\hline $\begin{array}{l}\text { EU } \\
\text { political } \\
\text { elites }\end{array}$ & $\begin{array}{l}\text { - Low level of } \\
\text { cooperation with } \\
\text { Eastern neighbors }\end{array}$ & $\begin{array}{l}\text { - Higher engagement with } \\
\text { Eastern neighbors in the } \\
\text { face of democratization }\end{array}$ & $\begin{array}{l}\text { - Creation of policy } \\
\text { instruments with the efforts of } \\
\text { national political elites to } \\
\text { democratize the country }\end{array}$ \\
\hline
\end{tabular}

Source: Own elaboration.

CHA has proven to be a useful approach to analyzing a complex process such as the territorial conflict of Ukraine and Georgia with Russia. The first step was to identify the different actors involved and their stakes in Ukraine and Georgia. Then, the comparison between both countries helped us to understand that the Georgian 
path to the conflict with Russia varied from that of the Ukraine because their different processes of democratization.

\section{Final Remarks}

This article highlighted the main characteristics of CHA, proposing that it is an approach that enhances the possibility of theorizing about complex social and political phenomena. One of the main characteristics of studies that fall under $\mathrm{CHA}$ is their ability to make careful theoretical generalizations that are based on contextualization. This contextualization is cautiously analyzed in the light of empirical observations based on comparative analyses. Furthermore, this comparison is historical in so far as it provides the opportunity to identify patterns of change over time. All of these elements distance CHA from the predictive inclination of other traditions.

Based on the methodological approaches that $\mathrm{CHA}$ advances, this article has explained how it is possible to theorize about historical processes. As such, it has attempted to build knowledge about the main methods of comparative historical analysis, which are essential for carrying out analyses of political developments and policy-making of modern states. All in all, key concepts (critical juncture, causal mechanism), theories (path dependency, historical institutionalism) and techniques (comparative method of difference and similarity, process tracing analysis) necessary for historical comparisons were explained.

More than ten years after the publication of the groundbreaking book Comparative Historical Analysis in the Social Sciences, written by James Mahoney and Dietrich Rueschemeyer, CHA has gained further relevance and attention in the social science research community. Part of this surge of interest can be attributed to what Mahoney and Rueschemeyer pinpointed as the three main distinguishing contributions of CHA to social science scholarship, namely, the identification and exploration of causal configurations in historical processes, the relevance of temporality (e.g., sequence) in causation, and the focus on contextualized small-N comparisons. Indeed, these contributions have helped CHA to consolidate itself as an alternative tradition to explain complex processes across different cases. Furthermore, as this article showed, CHA provides clearer guidelines on the strategies to assess complex causations. The two cases on which this article focused the application of these guidelines, the Ukrainian and the IS cases, helped us to more precisely sketch a general CHA framework based on the guidelines proposed by this approach.

As the brief analyses on the Ukrainian and IS cases illustrate, any comparative framework put forward under the CHA approach is devoid of any predefined 
theoretical orientation. One of the contributions of $\mathrm{CHA}$ is precisely that, to provide an understanding of the social and political sciences under theoretical pluralism. This means that as an approach that pursues theory building based on inductive analyses, CHA borrows from different theories to assess social and political processes.

The road ahead for CHA seems promising. As shown in this article, CHA offers the ability to develop a comprehensive frame for complex current phenomena. This does not mean that there are no challenges ahead. For example, the development of mid-range theories is not an easy task since the nature of theory development based on small-N is time-consuming. Also, although $\mathrm{CHA}$ has solid foundations, there is very little consensus on the methods of analyzing history. Before consolidating these methods, there is an urgent need to define the different modes of temporality, causal mechanisms, and type of institutional change. For now, CHA's main contribution will be that of knowledge accumulation and methodological innovation. With the emergence of CHA as an alternative within qualitative research, the field of social and political sciences has become methodologically richer.

- Hélder Ferreira Vale é Doutor em Ciência Politica e Sociologia pelo Instituto Universitário Europeu (Florenç,a, Itália) e pela Universidade Pompeu Fabra (Barcelona, Espanha). Professor da Faculdade de Pós-Graduação de Estudos Internacionais e Regionais (GSIAS) da Universidade de Hankuk (HUFS) na Coreia do Sul. Diretor do Departamento de Estudos Latino-Americanos da HUFS. E-mail: helder@hufs.ac.kr.

\section{Referências}

ALAGHA, Joseph. The Shifts in Hizbullah's Ideology. Amsterdam: Amsterdam University Press, 2006.

BLYTH, Mark. Great Punctuations: Prediction, Randomness, and the Evolution of Comparative Political Science. American Political Science Review, n. 100, p. 493-498, 2006.

CALVERT, Randall L. The rational choice theory of social institutions: cooperation, coordination, and communication. In: S. BANKS, Jeffrey; HANUSHEK, Eric Allen (eds.). Modern Political Economy: Old Topics, New Directions. Cambridge: Cambridge University Press, 1995, p. 216268.

CASIER, Tom. The EU's Two-Track Approach to Democracy Promotion: The Case of Ukraine". Democratization, v. 18, n. 4, p. 956-977, 2011. 
CAPOCCIA, Giovanni; KELEMEN, R. Daniel. The Study of Critical Junctures: Theory, Narrative, and Counterfactuals in Historical Institutionalism. World Politics, v. 59, n. 3, p. 341-369, 2007.

CHECKEL, Jeffrey T. Tracing Causal Mechanisms. International Studies Review, v. 8, n. 2, p. 362$370,2008$.

CHILDS, Steven. 2011. From Identity to Militancy: The Shi'a of Hezbollah. Comparative Strategy, v. 30, n. 4, p. 363-372.

CRONIN, Audrey Kurth. ISIS Is Not a Terrorist Group. Foreign Affairs, v. 94, n. 2, p. 87-98, 2015.

DELLA PORTA, Donatella; KEATING, Michael. Comparing approaches, methodologies and methods: Some concluding remarks. In: DELLA PORTA, Donatella; KEATING, Michael (eds.). Approaches and Methodologies in the Social Sciences: A Pluralist Perspective. Cambridge: Cambridge University Press, 2008.

FALLETI, Tulia; LYNCH, Julia. Context and Causal Mechanisms in Political Analysis. Comparative Political Studies, n. 42, p. 1143-1166, 2009.

FALLETI, Tulia. Decentralization and Subnational Governments in Latin America. Cambridge and New York: Cambridge University Press, 2010.

GEORGE, Alexander; BENNETT, Andrew. Case Studies and Theory Development in the Social Sciences. Cambridge and New York: Cambridge University Press, 2005.

GOERTZ, Gary; LEVY, Jack. Causal Explanation, Necessity Conditions and Case Studies. In: LEVY, Jack; GOERTZ, Gary (eds.). Explaining War and Peace: Case Studies and Necessary Condition Counterfactuals. Abingdon and New York: Routledge, 2007.

HANSON, Stephen E. Post-Imperial Democracies: Ideology and Party Formation in Third Republic France, Weimar Germany, and Post-Soviet Russia. East European Politics and Societies, n. 20, p. 343-372, 2006.

HAWKINS, Darren. Case Studies. In: LANDMAN, Todd; ROBINSON, Neil (eds.). The Sage Handbook of Comparative Politics. London: SAGE Publications Ltd, 2009, p. 50-66.

HÉRITIER, Adrienne. Causal Explanation. In: DELLA PORTA, Donatella; KEATING, Michael (eds.). Approaches and Methodologies in the Social Sciences: A Pluralist Perspective. Cambridge: Cambridge University Press, 2008.

KATZNELSON, Ira. Periodization and Preferences: Reflections on purposive action in Comparative Historical Social Science. In: MAHONEY, James; RUESCHEMEYER, Dietrich (eds.). Comparative Historical Analysis in the Social Sciences. Cambridge: Cambridge University Press, 2003.

KATZNELSON, Ira; WEINGAST, Barry R. Intersections Between Historical and Rational Choice Institutionalism. In: KATZNELSON, Ira; WEINGAST, Barry R. (eds). Preferences and Situations. Cambridge and New York: Cambridge University Press, 2005.

KNIO, Karim. Structure, Agency And Hezbollah: a Morphogenetic View. Third World Quarterly, v. 34, n. 5, p. 856-872, 2013.

KURZMAN, Charles. Can Understanding Undermine Explanation? The Confused Experience of Revolution. Philosophy of the Social Sciences, v. 34, n. 3, p. 328-351, 2004.

LANGBEIN, Julia; WOLCZUK, Kataryna. Convergence without membership? The Impact of the European Union in the Neighbourhood: Evidence from Ukraine”. Journal of European Public Policy, v. 19, n. 6, p. 863-881, 2012. 
LEVI, Margaret. Modeling Complex Historical Processes with Analytic Narrative. In: Mayntz, Renate (ed.). Akteure, Mechanismen, Modelle: Zur Theoriefähigkeit makro-sozialer Analysen. Frankfurt and Main: Campus Verlag. 2002.

LIPSET, Seymour Martin. Continental Divide: The Values and Institutions of the United States and Canada. New York: Routledge, 1990.

MAHONEY, James. Nominal, Ordinal, and Narrative Appraisal in Macrocausal Analysis. American Journal of Sociology, v. 104, n. 4, p. 1154-96, 1999.

MAHONEY, James; RUESCHEMEYER, Dietrich. Comparative Historical Analysis: Achievements and Agendas. In: MAHONEY, James; RUESCHEMEYER, Dietrich (eds.). Comparative Historical Analysis in the Social Sciences. Cambridge: Cambridge University Press, 2003.

MAHONEY, James; GOERTZ, Gary. A Tale of Two Cultures: Contrasting Quantitative and Qualitative Research. Political Analysis, n. 14, p. 227-249, 2006.

MAHONEY, James; THELEN, Kathleen. Explaining Institutional Change: Ambiguity, Agency, and Power. New York and Cambridge: Cambridge University Press, 2010.

MAHONEY, James. The Logic of Process Tracing Tests in the Social Sciences. Sociological Methods \& Research, n. 41, p. 570-597, 2012.

MANKOFF, Jeffrey. Russia's Latest Land Grab: How Putin Won Crimea and Lost Ukraine. Foreign Affairs, v. 93, n. 3, p. 19-28, 2014.

MARX, Anthony. Race Making and the Nation-State. World Politics, n. 48, p. 180-208, 1996.

MERTON, Robert K. Social Theory and Social Structure 3rd. New York: The Free Press, 1968.

MUNCK, Gerardo. Comparative Politics: Taking Stock and Looking Forward. Political Methodology Working Paper Series \# 30, 2010. (International Political Science Association [IPSA], Committee on Concepts and Methods).

NORTON, Augustus Richard. Amal and the Shia: Struggle for the Soul of Lebanon. Austin: University of Texas Press, 1987.

NUÑEZ VILLAVERDE, Jesús. El delirio califal del Estado Islámico en Irak y Siria. Politica Exterior, v. XXVIII, n. 161, p. 106-116, 2014.

PIERSON, Paul. "Increasing Returns, Path Dependence, and the Study of Politics". The American Political Science Review, v. 94, n. 2, p. 251-267, 2000.

PORTER, Bruce D.; SAIVETZ, Carol R. The Once and Future Empire: Russia and the "Near Abroad". The Washington Quarterly, v. 17, n. 3, p. 75-90, 1994.

PRZEWORSKI, Adam. Is the Science of Comparative Politics Possible? In: BOIX, Carles; STOKES, Susan C. (eds.) The Oxford Handbook of Comparative Politics. Oxford University Press, 2009.

RODDEN, Jonathan. Hamilton's Paradox: The Promise and Peril of Fiscal Federalism. Cambridge and New York: Cambridge University Press, 2005.

SALAMEY, Imad; PEARSON, Frederic. Hezbollah: A Proletarian Party with an Islamic Manifesto - A Sociopolitical Analysis of Islamist Populism in Lebanon and the Middle East. Small Wars \& Insurgencies, v. 18, n. 3, p. 416-438, 2007.

SASSEA, Gwendolyn. Linkages and the Promotion of Democracy: the EU's Eastern Neighborhood. Democratization, v. 20, n. 4, p. 553-559, 2013.

SKOCPOL, Theda. States and Social Revolutions: A Comparative Analysis of France, Russia and China. Cambridge and New York: Cambridge University Press, 1979.

SLATER, Dan. Revolutions, Crackdowns, and Quiescence: Communal Elites and Democratic Mobilization in Southeast Asia. American Journal of Sociology, v. 115, n. 1, p. 203-254, 2009. 
SLATER, Dan. Ordering Power: Contentious Politics and Authoritarian Leviathans in Southeast Asia. Cambridge University Press, 2010.

STEINMO, Sven. Historical Institutionalism. In: DELLA PORTA, Donatella; KEATING, Michael (eds.). Approaches and Methodologies in the Social Sciences: A Pluralist Perspective. Cambridge: Cambridge University Press, 2008.

STINCHCOMBE, Arthur. The Conditions of Fruitfulness of Theorizing about Mechanisms in Social Science. Philosophy of the Social Sciences, n. 21, p. 367-388, 1991.

STREECK, Wolfgand; THELEN, Kathleen. Introduction: Institutional Change in Advanced Political Economies. In: STREECK, Wolfgang; THELEN, Kathleen (eds.). Beyond Continuity: Institutional Change in Advanced Political Economies. Oxford: Oxford University Press, 2005.

THELEN, Kathleen. Historical Institutionalism in Comparative Politics. Annual Review of Political Science, n. 2, p. 369-404, 1999.

TOLSTRUP, Jakob. Studying a Negative External Actor: Russia's Management of Stability and Instability in the 'Near Abroad'. Democratization, v. 16, n. 5, p. 922-944, 2009.

ZIBLATT, Daniel. Structuring the State: The Formation of Italy and Germany and the Puzzle of Federalism. Princeton: Princeton University Press, 2006.

Texto recebido em 09 de março de 2015. Aprovado em 26 de março de 2015. 
